\title{
Ecologia și geografia pădurilor primare de mesteacăn din Rusia
}

\section{T. Yurkouskaya}

Yurkovskaya T., 2020. Ecology and geography of primary birch forests of Russia. Bucov. For. 20(2): 139-150

Abstract. Primary birch forests, as compared to secondary forests are strictly ecologically and geographically delimited and establish several distinct forests types on Russian territory. Betula czerepanovii, B. davurica, B. pendula, B. pubescens, $B$. ermanii, B. litwinowii, $B$. raddeana occupy the positions of dominant and co-dominant species within these communities. The spatial distribution of the primary birch forests is determined by: latitude, longitude and altitude. The main environmental factor influencing the distribution of primary birch forest in the context of geographical factors is the climate. The present paper introduces the analytical map of the primary birch forests from Russia and the 3D diagram of the forests' repartition and relative extent within their geographical range in the European and Asian parts of Russia. Two large categories of birch forests types can be distinguished. The first category includes birch forests with Betula pendula or/and B. pubescens as dominant species. Across their range, these forests establish either a compact cover (zonal and hemiboreal forests) or are fragmented and represented by birch groves within a steppic matrix (extrazonal forests). The second category includes birch forests with strictly delimited ranges. These forests are concentrated in the Northern and Southern parts of the boreal zone under extreme conditions and altitudinally, those reach the timberline belt in mountains, within continental Far-East and North-Pacific islands. Keywords: primary birch forests from Russia, analytic map, spatial distribution.

Author. Tatiana Yurkovskaya (yurkovskayatat@gmail.com), Komarov Botanical Institute of the Russian Academy of Sciences, Professora Popova str., 2, Saint Petersburg, 197376, Russian Federation

Manuscript received Octomber 23, 2020; revised December 15, 2020; accepted December 30, 2020; online first December 31, 2020.

\section{Introducere}

Pădurile primare de mesteacăn, spre deosebire de pădurile secundare sunt strict delimitate ecologic și geografic. În Europa, speciile de Betula sunt în general diseminate în diferite tipuri de păduri de foioase sau formează arborete pure păstrând o caracteristică importantă, sunt specii pioniere care se instalează la începutul succesiunilor secundare după perturbări naturale, precum incendii, sau antropice, precum tăieri rase (Moore 1979). Pădurile primare sunt definite drept păduri cu grad înalt de naturalitate ceea ce nu implică lipsa intervențiilor umane din trecut (Buchwald 2005). Sunt considerate ca fiind extrem de importante prin serviciile ecologice pe care le aduc în contextul general al restrângerii suprafețelor ocupate de aceste tipuri de păduri (Sabatini și al. 2020). Pe de altă parte, pădurile secundare sunt sec- 
vențe succesionale care se dezvoltă după perturbări majore care pot fi antropice (cum sunt tăierile rase) sau naturale (cum sunt incendidiile, doborâturile de vânt sau de zăpadă, inundațiile, etc.) (Chokkalingam și De Jong 2001). De exemplu, atât pădurile primare cât și cele secundare cu Betula pendula și Betula pubescens au o răspândire largă în Europa, în zonele sudice fiind cantonate în zonele montane ca specii de amestec dat fiind toleranța redusă la uscăciune, în timp ce în Europa de nord pot domina peisajul ca arborete pure. Pădurile edificate de cele două specii de mesteacăn, sunt larg răspândite în Rusia, în partea de est fiind înlocuite de Betula platyphylla.

Interesul abordării studiilor asupra acestor păduri în diferite regiuni ale Rusiei, în special al clasificării acestora a crescut în ultimele trei decenii (Vasilevich 1996, 1997, Degteva 2001, Ermakov 2003, Kessel et al. 2019). E de remarcat că aceste clasificări nu separă pădurile primare de cele secundare. Pentru o idee generală asupra extinderii pădurilor secundare de mesteacăn este suficientă inspecția vizuală a hărții pădurilor Rusiei (Bartalev și al. 2004). În acest context, lucrarea de față se referă exclusiv la pădurile de mesteacăn primare.

Dificultățile legate de studiul distribuției spaţiale din punct de vedere geobotanic şi geografic al speciilor lemnoase cu frunze mici în care intră și pădurile de mesteacăn rezidă nu numai în extinderea mare a arboretelor secundare în raport cu cele primare şi mai ales din separarea celor două categorii. Cea mai mare dificultate întâmpinată de botaniștii ruși constă în acordarea unui statut taxonomic clar speciilor de mesteacăn care sunt dominante sau co-dominante.

Speciile de mesteacăn sunt foarte polimorfe, fiind caracterizate de existența mai multor forme subspecifice, datorită hibridizării frecvente, din care motiv nu există o sistematică general acceptată a genului Betula (Palmé şi al. 2004, Ashburner și Mc Allister 2013, Terieiev și al. 2019). Taxonomiştii care adoptă conceptul monotipic al speciei precum N.N. Tselev (2002) se referă la 30 de specii distinc140 te în cadrul genului așa cum apare în volumul 11 din "Flora of Eastern Europe". Un punct de vedere opus este adoptat de A.K. Skvortsov (2002) care exclude din 6 specii de Betula - 2 specii. Aceste specii excluse apar ca dominante în arboretele ilustrate în harta atașată acestei lucrări în conformitate cu opinia lui S.K. Cherepanov (2007). Din cele menționate reiese că genul Betula este un gen dificil din perspectivă taxonomică și nomenclaturală.

Articolul propus se bazează pe o analiză a hărții de vegetație a URSS analiza la scară redusă pentru uzul studenților din 1990, o hartă analitică fiind construită în baza acestei hărți de Yurkovskaya și colaboratorii în 2012.

\section{Material și metodă}

Harta analitică a avut la bază informațiile de teren din diferite regiuni ale Rusiei și o analiză a literaturii de specialitate.

Harta distribuției pădurilor primare de mesteacăn s-a realizat pe baza metodei itinerante de studiu a vegetaţiei (Shennikov 1938) și metoda clasică, cartografică (Sochava 1979, Cristea et al. 2015).

\section{Rezultate}

Speciile genului Betula care edifică fitocenozele forestiere redate pe hartă ca specii dominante și subdominante sunt următoarele: Betula czerepanovii, B. davurica, B. pendula, $B$. pubescens, B. platyphylla, B. ermanii, $B$. litwinowii, $B$. raddeana, frecvent alături de Populus tremula.

Legenda hărții analitice a pădurilor primare de mesteacăn (figura 1) conține 9 elemente care reprezintă categorii de rang înalt ale învelișului vegetal. Aceste elemente corespund rangurilor de clasă sau grupări de asociații corespunzătoare unităților delimitate de școala de geobotanică de la Leningrad (Shennikov 1964). Este un fapt cunoscut că unitățile de vegetație redate pe hărți la scară redusă cores- 


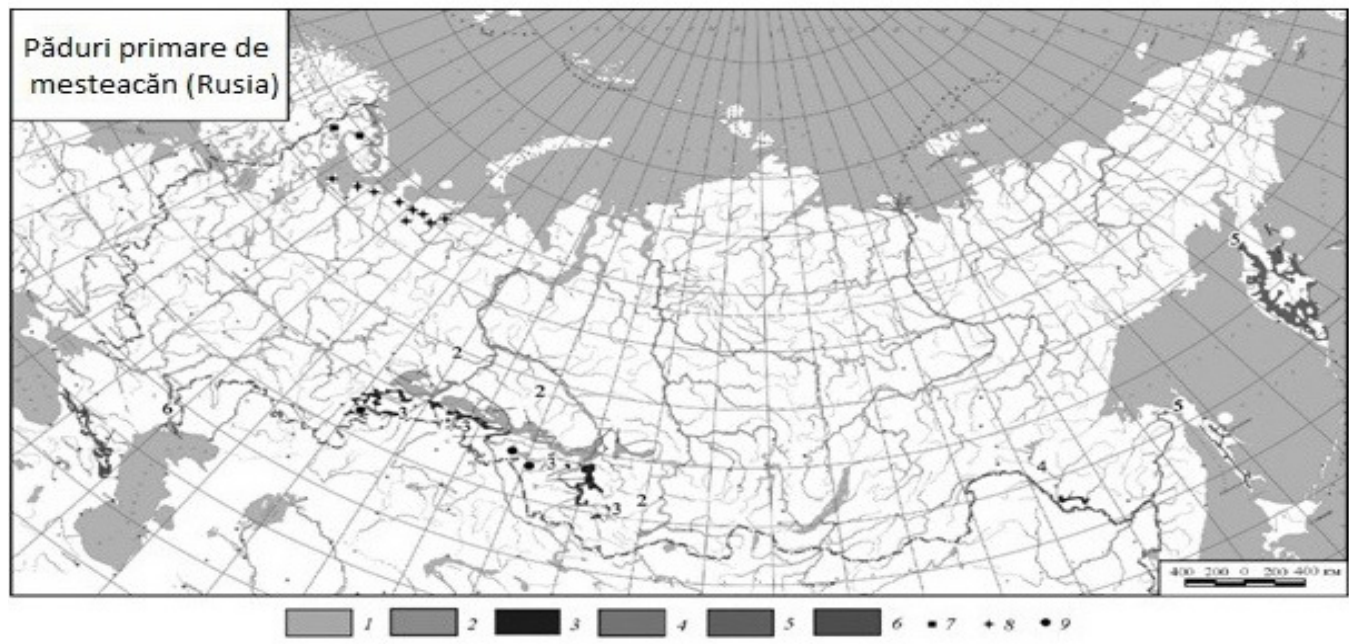

Figura 1 Harta pădurilor primare de mesteacăn din Rusia.

Map of primary birch forests in Russia.

Legendă

1. Sub-tundră cu păduri de mesteacăn (Betula czerepanovii, Picea obovata) din regiunea Barents.

2. Păduri hemi-boreale, vest-siberiene cu mesteacăn și plop tremurător (Betula pendula, Populus tremula) cu strat ierbos.

3. Silvo- stepă vest-siberiană cu mesteacăn și plop tremurător (Betula pendula, Populus tremula) cu strat de ierburi stepice.

4. Păduri de mesteacăn (Betula davurica, B. platyphylla) extrem-estice cu strat de ierburi stepice.

5. Păduri de mesteacăn cu Betula ermanii cu strat de ierburi înalte din insulele Pacificului de nord.

6. Păduri Caucaziene subalpine cu Betula litwinowii.

Unități non-scalare

7. Păduri și rariști montane de mesteacăn (Betula czerepanovii) din zona peninsulei Kola și Karelia.

8. Rariști de mesteacăn în subtundră (Betula czerepanovii, Picea obovata), în nordul Câmpiei Ruse.

9. Păduri de mesteacăn la limita cu stepele din nordul Siberiei de vest (Betula pendula, B. pubescens).

10. A zecea grupă ce cuprinde pădurile de mesteacăn Siberiene de mlaștină (Betula pubescens) din estul Europei care nu sunt figurate în legenda hărții datorită limitelor impuse de scară.

pund cu aproximație unor ranguri de clasificare. Totuși, în alcătuirea hărților de vegetație lipsa de uniformitate și consecvență a diferitelor sisteme de clasificare este compensată de posibilitatea includerii pe hartă a diferiților sintaxoni în baza speciilor dominante și a speciilor diferențiale prezente în legendă.

\section{Pădurile de mesteacăn din subtundră și zona subalpină din regiunea Barents}

În nord-vestul Rusiei, în peninsula Kola, limita nordică a vegetaţiei lemnoase este formată din rariști de tip sub-tundră sau pre-tundră domi- nate de Betula czerepanovii.

Această specie de mesteacăn a fost descrisă de N.I. Orlova (Orlova 1976, 1978) a cărei încadrare a fost acceptată de mulți taxonomiști ruși în publicații relevante (Cherepanov 2007, Tzvelev 2002, Kravchenko, 2007 și altii). Separarea speciei Betula czerepanovii de B. tortuosa a fost larg acceptată de botaniștii din Europa de nord precum L. Hämet-Ahti (1987) care a scris un articol pe această problemă din perspectivă taxonomică, geografică și fitosociologică. Totuși, Hämet-Ahti contestă statutul de specie separată şi încadrează pe $B$. czerepanovii ca subspecie a lui $B$. pubescens 
și anume, Betula pubescens ssp. czerepanovii (Orlova) Hämet-Ahti.

Arealul lui Betula czerepanovii se extinde spre est până la fluviul Enisei dar această limită încă mai necesită clarificări. Extinderea fitocenotică a rariștilor de mesteacăn edificate de Betula czerepanovii nu are limite clare în nord-est, în partea asiatică a Rusiei.

Pe hartă se diferențiază clar o bandă de rariști de mesteacăn în sub-tundra din peninsula Kola (figura 1, tipul 1). Extinderea totală a ariei ocupate în sub-tundră de păduri este între $33^{\circ}$ și $36^{\circ}$ longitudine estică. Această arie acoperă o bandă îngustă între $69^{\circ}$ latitudine nordică, în vest și $67^{\circ}$ latitude nordică, în est. Altitudimea medie față de nivelul mării este de $250 \mathrm{~m}$, cu variaţii altitudinale între 500 și $200 \mathrm{~m}$. Banda de păduri din tundră delimitează limita nordică a pădurilor pentru care s-au realizat puține relevee în peninsula Kola. Cele mai complete relevee geobotanice au fost realizate încă în 1932 de către G.D. Zinserling care a identificat 11 asociații și a subliniat că rariștile de mesteacăn cu licheni domină în zonă, propunând o schemă de ordonare folosind metoda lui Sukachev. Aceste rariști au fost studiate la limita lor vestică, în apropiere de Norvegia de către M.L. Ramenskaya (2015b).

În câmpia ce se extinde la est de Marea Albă, limita nordică a pădurilor este marcată de prezența speciei Picea obovata iar rariștile conțin pe alocuri Betula czerepanovii. Frecvent, în bazinul inferior al râului Sula situate în pădurile de tundră nordice, apar rariști de Betula czerepanovii. Pe hartă sunt marcate cu simboluri non-scalare (figura, tipul 8). În aceste zone pădurile apar în habitate pe nisipuri marcate de uscăciune și oligotrofe. Domină lichenii ca acoperire în stratul ierbos, în timp ce mușchii sunt corticoli găsindu-se la baza trunchiurilor. Structura acestor fitocenoze de rariști de mesteacăn cu licheni corespunde celor descrise de Zinserling în peninsula Kola.

Betula czerepanovii formează comunități distincte de rariști cu exemplare deformate de mesteacăn în limita nordică a subzonei boreale unde se găsesc mai ales pe nisipurile de coastă 142 și plajele pietroase ale lacurilor (de exemplu, în zona lacului Kuopsuyarvi din Karelia). În această comunitate, stratul de ierburi și subarbuști este dominat de Chamaepericlymenum suecicum). Crânguri ce ocupă surprafețe restrânse și rariști de Betula czerepanovii sunt caracteristice unor insule din Marea Albă fiind găsite în special pe dunele de nisip (de exemplu, pe coastele Mării Albe, aproape de satul Nizhnyaya Zolotitsa, regiunea Arkhangelsk). Nu sunt figurate pe hărțile la scară redusă, inclusiv pe cele analitice.

Pădurile de mesteacăn dominate de Betula czerepanovii formează un etaj la altitudini înalte în zona de sub-goletz, în munţii localizați la limita nordică a subzonei boreale atât în peninsula Kola, cât şi în nordul Kareliei (Khibiny, tundra Lovozero, crestele tundrei Zaimandrovsky, munții Kivakka, Nuorunen, Sieppitunturi, etc.) (figura 1, tipul 7). Goletz reprezintă golul de munte lipsit de vegetație în munţii din cuprinsul Siberiei. Acest etaj de rariști de mesteacăn cu Betula czerepanovii în zona montană înlocuiește taigaua montană formată mai ales din păduri de molid (Picea obovata), uneori de păduri de pin, localizate la altitudini de 350-400 m (Yurkovskaya 1993, Kholod 1994). Tipologia rariștilor montane de mesteacăn cu exemplare deformate din regiunea Kola-Karelia a fost tratată în câteva lucrări (Zinserling 1932, Avrorin et al. 1936, Nekrasova 1935, 1938, Neshataev și Neshataeva 1993 etc.). În munții din tundra Zaimandrovsky (Rezervația naturală Lapland), comunitățile de rariști au fost tratate detaliat în lucrările T.P. Nekrasova, apoi de către V. Yu. şi Neshataeva. Autoarele prezintă o listă a sintaxonilor pe care îi compară cu sintaxonii descriși anterior de Nekrasova. Conform acestor date, stratul de arbori din rariști este compus din Betula czerepanovii și $B$. kusmisscheffii. Comunități ale asociației Parvo-Betuletum empetroso-myrtillosum domină alături de varietăți de păduri de mesteacăn cu strat de graminee, compozițiile fiind dictate de nivelul de aprovizionare cu apă. În apropierea crestelor, densitatea și înălțimea arborilor descrește iar zona de tundră montană 
conține exemplare izolate de mesteacăn care vegetează în locuri protejate de vânt, acoperite de zăpadă pe timpul iernii. Din păcate autorii citați indică în mod incorect aceste comunități ca fiind restrânse la nivelul etajului subalpin. Se știe în momentul de față că zonarea altitudinală în taiga este diferită de cea a zonei nemorale din Eurasia. În munţii din peninsula Kola și din Karelia, se diferențiază taigaua montană, rariști de arbori deformați (sub-goletz) și tundra montană (goletz) (Kholod, Yurkovskaya, 2013).

În masivele Khibiny și Lovozero, se remarcă aceeași zonare altitudinală. Etajele sunt mai clar diferențiate, în special etajul de tundra montană, aceștia fiind cei mai înalți munți din Fennoscandia de est. Zona de rariști de mesteceni deformați din munții Khibiny se extinde între 400 și $600 \mathrm{~m}$ altitudine față de nivelul mării (Avrorin et al. 1936, Vorobyeva 1960, Kryuchkov 1960). Pe pantele estice și vestice ale munților Urali, Betula czerepanovii formează rariști care, în combinație cu poienile formează o o bandă continuă care se extinde de la coastele oceanului Arctic până în Uralii de sud. Apare o singură discontinuitate la nivelul Uralilor de mijloc. Zona de rariști de mesteacăn și păduri cu arbori deformați din Urali înlocuiește taigaua de conifere la altitudini de $150 \mathrm{~m}$ în nord până la $1000 \mathrm{~m}$ fața de nivelul mării, în sud (Govorukhin, 1960; Gorchakovsky, 1966; Degteva, 2001). În partea nordică a Uralilor subpolari, la altitudini inferioare apar rariștile de mesteacăn. Pe harta analitică, aceste rariști nu sunt marcate dar sunt figurate în profilele ce redau vegetaţia de pe pantele estice şi vestice ale munților Urali în lucrările lui P.L. Gorchakovsky și V.S. Govorukhin.

\section{Pădurile de mesteacăn, pădurile de mesteacăn și plop, și pădurile extrazonale din Siberia de vest}

Pe hartă aceste păduri sunt reprezentate printr- un simbol non-scalar (figura 1, tipurile 2, 3, 9). Simbolurile pentru scări mari sunt utilizate pentru trasarea extinderii spaţiale și a distribuției; sunt astfel marcate cele mai extinse păduri de mesteacăn, studiate intens în decursul secolului trecut și la începutul acestui secol (Gorodkov 1915, Isachenko şi Lukicheva 1956, Krylov 1953, 1961, Lapshina 1963,Ilyina et al. 1985, Ermakov 2001, 2003 etc.). Acestea au fost figurate în hărțile la scară mică a URSS precum şi în hărțile regionale. Terminologia folosită corespunde legendei modificate a Hărții de Vegetație de Uz Universitar (1990). Cea mai detaliată legendă este ataşată hărții Vegetației Siberiei De Vest la scara de 1: 1.500 .000 (1976). Pe harta de vegetaţie de uz universitar și pe hărțile analitice aceste păduri sunt marcate numai cu două unități datorită restricțiilor impuse de scară. Totuși, pentru caracterizarea acestor păduri am folosit informația din releveele prezentate în articolul lui N.N. Lavrenko (1985) care le-a identificat corect atât în privința compoziției cât și a răspândirii geografice. Autoarea a arătat că pădurile indigene cu mesteacăn sau amestec de mesteacăn și plop tremurător (ocazional plopișuri pure) înlocuiesc pădurile Europene de foioase precum și cele de amestec de foioase și conifere în sudul Siberiei de vest în conditiile climatului continental. Pădurile de foioase sunt absente în Siberia iar cauza este climatul continental (Box et al. 2001). În vest, în trans-Urali, pinul este răspândit împreună cu mesteacănul, apărând și amestecuri sub forma pădurilor de pin și mesteacăn sau de mesteacăn dominant și pin, pădurile pure de mesteacăn fiind rare. $\mathrm{Cu}$ toate acestea, pe hărțile analitice aceste tipuri de păduri nu sunt tratate separate în contextul general al pădurilor de mesteacăn.

Pădurile de mesteacăn și cele de mesteacăn şi plop tremurător (Betula pendula, Populus tremula) cu strat ierbos de graminee acoperă zona hemi-boreală a Siberiei vestice (figura 1, tipul 2). Formează o bandă compactă și extinsă latitudinal între $65^{\circ}$ și $85^{\circ} \mathrm{E}$. Aceste păduri sunt împărțite în două sub-zone; în sub-zona nordică există păduri de mesteacăn cu strat ierbos și subarbustiv diversificat în care intră specii tipice de taiga precum Trientalis europaea, Rubus arcticus, Paris quadrifolia, etc. Arboretele dense sunt edificate de specii care 
pot ajunge la 20 m înălțime în compoziția cărora intră Betula pendula, B. pubescens, iar sporadic apare Populus tremula. Stratul arbustiv este bine dezvoltat iar în stratul ierbos intră specii de graminoide care ajung la 1-1,5 m înălțime, între care specia frecvent întâlnită este Calamagrostis arundinacea. Diversitatea și abundența graminoideleor crește în pădurile care au suferit perturbări.

A doua sub-zonă cuprinde partea sudică a benzii hemi-boreale unde participarea plopului în edificarea arboretelor crește apărând și arborete pure de plop. Densitatea și înălțimile la nivelul arboretelor se reduc iar specii răspândite în nord precum sălciile și zmeurul dispar. În stratul ierbos domină graminoidele între care figutrează Calamagrostis epigeios și C. arundinacea.

Păduri de mesteacăn, sau de amestec cu mesteacăn și plop (Betula pendula, Populus tremula), cu strat ierbos dominat de graminoide acoperă silvostepa Siberiei de vest (figura 1, tipul 3). N.N. Lavrenko consideră că aceste păduri sunt asemănătoare celor sudice hemi-boreale, fiind o versiune sclerofilă a acestora. Această bandă latitudinală este profund modificată antropic astfel încât, în momentul de faţă este extrem de dificil de stabilit care este proporția de păduri și pajiști stepice care au existat înainte de modificarea vegetației inițiale. Pe harta analitică, ariile cu păduri de mesteacăn sau cele în amestec cu plop au limite imprecise fiind incluse suprafețe de comunități ale formaţiunilor de ierburi. Simbolurile non-scalare marchează numai la sudul zonei de silvo-stepă şi în nordul stepei prezența mesteacănului și a plopilor pe fondul vegetației stepice, în prezent suprafețe aproape integral agricole (figura 1, tipul 9). Înălțimile arborilor în aceste păduri ating dimensiuni modeste, frecvent de $10 \mathrm{~m}$ şi rar, 15 m. Subarboretul este slab dezvoltat, alătuit din specii precum Calamagrostis epigeios şi Brachypodium pinnatum, fiind reprezentate speciile haloxerofite și ierburile stepice. N. B. Ermakov (2003) subliniază că în silvostepă, pădurile de mesteacăn și amestec de mesteacăn cu plop se găsesc numai în habitate din 144

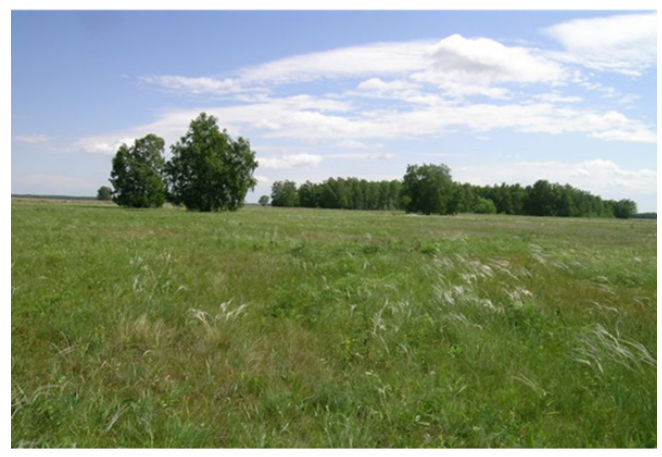

Figura 2 Aspect de pădure extrazonală de mesteacăn, kolki, în silvostepa Barabinskaya (foto N.P. Kosykh).

Aspects of extrazonal birch forest, kolki, in Barabinskaya forest-steppe (photo N.P. Kosykh).

afara placorului și sunt concentrate în microdepresiuni. Pe de altă parte, N.N. Lavrenko le consideră ca fiind păduri zonale. Este posibil ca acest dezacord să fi apărut ca urmare a faptului că pădurile de mesteacăn din habitate halohidromorfice au rămas intacte până în prezent. În cursul uneia din deplasările din cadrul simpozionului dedicat mlaștinilor și organizat de N.P. Mironycheva-Tokareva și N.P. Kosy$\mathrm{kh}$, autoarea acestui articol a avut posibilitatea de a vedea pe teren, în zona silvostepei Barabinskaya pădurile extrazonale de mesteacăn numite kolki, localizate în bazinul hidrografic și nu în microdepresiuni sau alte denivelări pozitive ale terenului.

Trebuie remarcat faptul că distribuția pădurilor de mesteacăn este asociată nu numai cu gradientul climatic al continentalităţii ci şi cu salinizarea solului care este pregnantă în silvostepă. Hidromorfismul solurilor din Siberia de vest este hotărâtor în acest context deoarece în condiții de hidromorfism crescut Betula pubescens domină arboretele pe întreaga suprafață extinsă latitudinal și ocupată de păduri de mesteacăn și în amestecurile cu plop.

Ultima analiză aprofundată a pădurilor de mesteacăn din Siberia de vest a fost făcută de N.B. Ermakov (Ermakov 2001, 2003, Ermakov et al. 2000) care a propus clasificarea pe 
principiile sistemului Braun-Blaquet, incluzând aceste păduri în clasa Brachypodio pinnati-Betuletea pendulae (Ermakov, Koroluyk and Lashchinsky, 1991). Pădurile au fost incluse într-o categorie geografică în afara ierarhiei fitosociologice, a pădurilor hemi-boreale împreună cu alte clase de păduri din nordul continental al Asiei.

\section{Păduri de mlaștină cu mesteacăn din partea est-Europeană a Siberiei.}

Grupul de păduri de mlaștină cu mesteacăn luate în considerare în acest articol nu sunt figurate pe hartă din cauza scării. Ele ocupă suprafețe extinse în partea est-Europeană şi cea de vest a Siberiei, în câmpiile boreale și hemi-boreale și pătrund în Siberia Centrală pe malul drept al fluviului Enisei. Arboretele sunt edificate de specia Betula pubescens iar extinderea lor geografică corespunde în Rusia pădurilor secundare de mesteacăn. Cu toate acestea, extinderea lor condiționată de factorii ecologici este îngustă și specifică. Această unitate include comunităţi care prezintă un strat al arborilor dominat de mesteacăn pe depozite de turbă de tranziție sau la altitudini mici. Aceste păduri se numesc sogra şi sunt comune în Trans-Urali şi Siberia de vest. Grosimea depozitelor de turbă variază între 0,5 și 4 m. Acestor păduri le sunt caracteristice habitatele cu apă stagnantă în sol şi $\mathrm{pH}$ de 4.

Pădurile din mlaștini cu mesteacăn sunt răspândite în Belarus, în special în zona Poplysye, considerate fiind de către eminentul geobotanist V.S. Geltman $(1958,1982)$ ca fiind primare. Autoarea acestui articol împărtășește această opinie, cu toate acestea există și alte opinii asupra originii acestui tip de păduri. Astfel, V.I. Vasilevich (1997), consideră că pădurile de mlaștină cu mesteacăn sunt secundare dar cu o istorie îndelungată la nord-vest de Rusia justificând această opinie cu prezența molidului în subarboret. Consider că procesul de formare a mlaștinii odată început evoluează succesional către condițiile favorabile instalării pădurii boreale de molid care va înlocui mesteacănul numai în cazurile speciale în care habitatele de mlaştină ajung să fie drenate.

\section{Păduri hemiboreale din estul extrem cu Betula davurica și B. platyphylla}

Pe hartă pădurile din estul extrem cu Betula davurica și B. platyphylla cu ierburi stepice sunt figurate într-un singur loc (igura 1, tipul 4). Localizarea de pe hartă indică zona de interfluviu ale râurilor Zeya și Bureya, deasupra localității Blagoveshchensk $\left(52^{\circ} \mathrm{N}\right.$ și $\left.128^{\circ} \mathrm{E}\right)$. Ca precizare, zona ar trebuie numită câmpia hemi-boreală Cis-Amur Zeya-Bureya.

În momentul de față, pădurile cu Betula davurica și $B$. platyphylla sunt diseminate în sudul Extremului Orient fără a ocupa suprafețe extinse. Aria redată pe hartă este exagerată în comparație cu aria din harta originară, acest fapt fiind determinat de nevoia de a atrage atenția geobotaniştilor asupra acestor păduri puțin cercetate. Cea mai detaliată informație asupra acestor păduri a fost găsită într-un articol a lui V.V. Lipatova (1969), o comunicare destul de laconică. De exemplu, informații asupra poziţiei latitudinale a pădurilor (statut zonal sau sub-zonal) și asupra dinamicii sunt contradictorii. Lipatova consideră că aceste păduri sunt serii succesionale ale unor comunități hemi-boreale derivate, dominate de larice sau pin. Pe Harta Vegetaţiei URSS de Uz Universitar sunt tratate drept păduri primare plasate în secțiunea pădurilor boreale și sub-secțiunea specială a pădurilor de silvo-stepă împreună cu pădurile Siberiei de vest, de plop și mesteacăn din silvo-stepă. Consider că această încadrare botanică și geografică pădurilor în discuție se datorează lipsei de claritate în aprecierea poziției lor fitocenologice, a distribuției geografice și a poziției în sistemul de clasificare. Se pare că aceste păduri aparțin tipului de păduri de foioase.

\section{Pădurile cu Betula ermanii din insulele Pacificului}

Pădurile de Betula ermanii sunt cele mai răspândite păduri în Kamchatka ocupând mai mult de 50\% din suprafața împădurită (Neshataeva 
2009). Sunt caracteristice și pentru insulele din Pacific precum Sakhalin și insulele Kurile (Harta Vegetației URSS de Uz Universitar, 1990; figura 1, tipul 5). Kamchatka este o peninsulă dar este considerată teritoriu insular, la nord fiind conectată cu continentul. În mod cert este un teritoriu diferit sub aspect geobotanic și floristic de teritoriile insulare (Kamelin 2004). În afara Rusiei, pădurile de Betula ermanii sunt răspândite în nordul și centrul Japoniei unde se extind în zonele montane alături de speciile de bambus. Pe baza acestei răspândiri sunt numite păduri nord-Pacifice, insulare şi boreale cu Betula ermanii.

Sunt păduri mai intens studiate decât alte tipuri de păduri primare de mesteacăn. Cea mai recentă și completă informație asupra pădurilor de Betula ermanii din Kamchatka este monografia scrisă de V. Yu. Neshataeva (2009) în care apare cea mai completă clasificare fitocenologică a acestor păduri. Clasificarea include 5 grupe de asociații, 8 asociații, 13 sub-asociații şi 8 variante.

Pădurile de $B$. ermanii sunt caracteristice regiunilor insulare din Pacificul de nord cu un climat oceanic umed și răcoros. Arealul ocupat de aceste păduri este fragmentat dar vast atât în sens longitudinal cât și latitudinal. În peninsula Kamchatka care ocupă un teritoriu între $51-60^{\circ} \mathrm{N}$ şi $156^{\circ}-163^{\circ} \mathrm{E}$ predomină pădurile montane a căror particularitate constă în prezența pădurilor de $B$. ermanii unde formează un etaj la altitudini înalte. Zonarea altitudinală caracteristică din centrul peninsulei se modifică în direcție nordică și sudică în funcție de modificarea latitudinală a climei. Arboretele sunt restrânse în habitate cu un strat gros de zăpadă și nu se instalează în zone cu permafrost sau în zone umede.

În insula Sakhalin $\left(46-53^{\circ} \mathrm{N}\right.$ and $141^{\circ}-$ $142^{\circ} \mathrm{E}$ ) pădurile de $B$. ermanii apar în etajul subalpin și sunt reprezentate de asociații în care vegetează arbuști, ierburi graminoide, pini pitici și bambus (Isachenko și Lukicheva 1956, Kabanov 1972).

La nord de insulele Kurile nu se găsesc păduri de $B$. ermanii dar în insulele din centrul și 146 sudul arhipelagului acestea vegetează pe terasele coastelor marine la altitudini de 800-900 $\mathrm{m}$. Sunt reprezentate prin comunităţi cu arbuști nemorali și bambus fiind apropiate de cele japoneze în privința compoziției.

Distribuția geografică a pădurilor de $B$. ermanii este determinată atât de climat cât și de existența zonelor cu vulcanism intens.

\section{Păduri Caucaziene subalpine de mesteacăn}

Pădurile edificate în principal de Betula litwinowii din această zonă sunt caracterizate de habitusul lor deformat și au fost descrise de o serie de cercetători ai vegetaţiei Caucazului. Între geobotaniștii georgieni studii excelente au realizat A.G. Dolukhanov (1939, 1956), I.I. Tumadzhanov (1960 a, b, 1980) și K.Yu. Golgofskaya (1959) la care s-au adăugat studii de data recentă (Kessel et al. 2019). Staţiunea Kazbegi aparţinând de Institutul Botanic din cadrul Academiei de Știinţe a Georgiei a găzduit una din vizitele pe teren a comitetului editorial al Hărții de Vegetaţie a Europei condusă de R. Neuhäusl în contextul identificării fitocenozelor caracteristice zonei între care figurează şi asociaţia $B e$ tuletum rhododendrosum cu Betula litwinowii și Rhododendron caucasicum.

Betula litwinowii este o specie tipică pentru pădurile cu arbori deformați subalpine, cu o răspândire restrânsă la o bandă de vegetație între 2000 și $2400 \mathrm{~m}$ ajungând până la 2700 m în depresiunile închise și marcate de uscăciune (figura 1, tipul 6). Se asociază în acest tip de pădure cu $B$. raddeana. Cu toate că sunt simpatrice, speciile aparțin la secțiuni diferite în cadrul genului Betula: B. litwinowii este încadrată în secțiunea Albae în timp ce $B$. raddea$n a$ este încadrată în secțiunea Costatae. Fiind considerată o specie relictă, $B$. raddeana apare în pădurile de mesteacăn din Dagestan fără să devină dominantă (Dibirov 2007). D.S. Kessel şi co-autorii au lucrat în Dagestan şi Teberda constatând că cele două specii se diferențiază foarte puțin din punct de vedere morfologic în condiții concrete de teren.

Betula litwinowii are un habitus caracteris- 
tic, cu înalţimi modeste, între 12 și 16 m, cu un ritm lent de creștere, frecvent cu aspect arbustiv, coroană neregulată și trunchi curbat. Pătrunde în partea inferioară a etajului pădurilor avansând în grohotișurile lăsate de avalanșe. Invadează terenurile perturbate de incendii și despăduriri contribuind la compoziţia comunităților în succesiuni secundare.

O caracteristică a etajului subalpin din munții Caucaz este combinația de păduri subalpine, arbuști, ierburi înalte și pajiști, cel mai frecvent rezultate din aceleaşi procese genetice (Tumadzhanov 1980). Aria ocupată de pădurile de mesteacăn cu exemplare deformate este exagerată din cauza limitărilor impuse de scara hărții care a necesitat eliminarea altor tipuri de comunităţi (figura 1) .

Figura 3 redă ponderea diferitelor tipuri de fitocenoze edificate de specii de Betula care se regăsesc în structura hărții de vegetație a Rusiei conform suprafețelor de teren ocupate. Se observă că suprafețele ocupate de pădurile de mesteacăn Caucaziene se extind la cele mai mari altitudini comparativ cu celelalte tipuri de fitocenoze cu Betula prezentate.

\section{Discuții și concluzii}

Distribuția geografică a pădurilor de mesteacăn urmează același principiu general valabil pentru vegetaţie, depinde de gradienții latitudinali, longitudinali şi altitudinali iar acest fapt este ilustrat de reprezentarea tridimensională folosind ca axe cele trei categorii de coordonate spațiale. Se remarcă arealul fragmentat al unor tipuri de păduri edificate de specii din genul Betula (tipul 5 și tipul 10,vezi legenda figurii 3) și arealele compacte ale tipurilor de pădure cu Betula în alte cazuri (tipul 1, tipul 2, tipul 4 și tipul 6).

Factorii ecologici responsabili de diferențierea spațială a tipurilor de păduri de mesteacăn sunt în principal, cei climatici: regimul radiativ, suma temperaturilor pozitive, lungimea sezonului de vegetație. Factorii topoclimatici și cei edafici locali nu au fost luați în considerare în

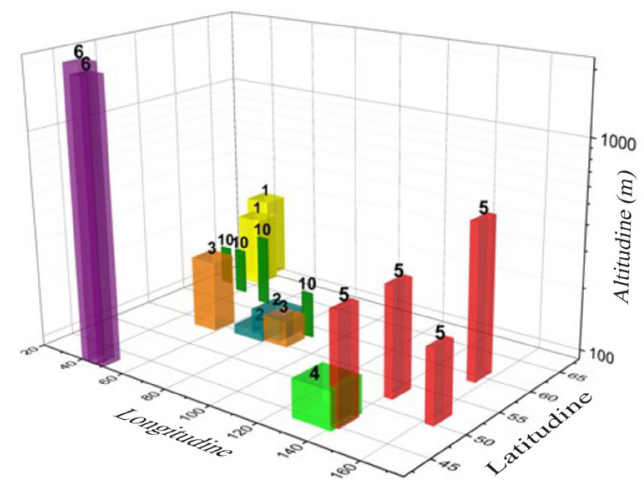

Figura 3 Reprezentarea ponderii pădurilor de mesteacăn primare pe harta de vegetație a Rusiei în funcție de latitudine, longitudine (exprimate în unități metrice liniare) și altitudine (în logaritmi).

Representation of the share of primary birch forests on the Russian vegetation map by latitude, longitude (expressed in linear metric units) and altitude (in logarithms).

\section{Legendă}

1. Sub-tundră cu păduri de mesteacăn (Betula czerepanovii, Picea obovata) din regiunea Barents.

2. Păduri hemi-boreale, vest-siberiene cu mesteacăn și plop tremurător (Betula pendula, Populus tremula), cu strat ierbos.

3. Silvostepă vest-siberiană cu mesteacăn și plop tremurător (Betula pendula, Populus tremula) cu strat de ierburi stepice.

4. Păduri de mesteacăn (Betula davurica, B. platyphylla) extrem-estice cu strat de ierburi stepice.

5.Păduri de mesteacăn cu Betula ermanii cu strat de ierburi înalte din insulele Pacificului de nord.

6. Păduri Caucaziene subalpine cu Betula litwinowii.

7. Păduri și rariști montane de mesteacăn (Betula czerepanovii) din zona peninsulei Kola și Karelia.

8. Rariști de mesteacăn în subtundră (Betula czerepanovii, Picea obovata), în nordul Câmpiei Ruse.

9. Păduri de mesteacăn la limita cu stepele vest-Siberiene nordice (Betula pendula, B. pubescens).

10. A zecea grupă ce cuprinde pădurile de mesteacăn Siberiene de mlaștină (Betula pubescens) din estul Europei. 
lucrarea de față. Corelarea cu factorii de mediu a asociațiilor a fost tratată pe larg de alți autori, de exemplu, pentru asociațiile edificate de Betula czerepanovi (Zinserling 1932, Ramenskaya 2015a, b, Neshataev și Neshataeva 1993).

Se disting două categorii de păduri de mesteacăn, în raport cu distribuția lor geografică. Prima categorie include păduri în care domină Betula pendula sau/și B. pubescens. În arealul ocupat, aceste tipuri de păduri vegetează pe suprafețe compacte (zonal, hemiboreale) cum este tipul 2 sau sunt fragmentate și se prezintă sub forma unor rariști într-o matrice edificată de vegetația stepică (extrazonal) cum sunt pădurile încadrate la tipul 2 și tipul 9. În diferite zone co-există cu păduri de mesteacăn secundare. Limitele pădurilor extrazonale sunt determinate latitudinal de silvostepă și de subzona nordică a stepei. În afara influențelor determinate de factorii climatici zonali, organizarea spațială a pădurilor de mesteacăn este determinată și de continentalitate sau/şi creșterea salinităţii solului.

Distribuția pădurilor de mesteacăn de mlaștină din Siberia est-Europeană are un aspect particular: extinderea spațială vastă este una fragmentată, cu un caracter extrazonal. Pădurile de mesteacăn se prezintă ca enclave în pădurile de conifere. Nu sunt afectate de creșterea continentalității pe măsura avansării spre est fiind asociate unor nivele crescute de umiditate generate de stratul freatic la suprafață, înmlaștinare, inundare periodică sau acumulare de turbă. $\mathrm{Cu}$ toate că sunt dependente de un nivel crescut de umiditate, sunt sensibile la salinizare și au nevoie de un aport continuu de apă din rezervoare dulcicole. Aceste fitocenoze înlocuiesc arinul în habitatele de mlaștină în Siberia. În Europa arealele speciilor de Betula se intersectează cu cel al arinului (Alnus gluti$n o s a$ ), mesteacănul ocupând habitatele reci și cu un conţinut scăzut de nutrienți.

A doua categorie include tipurile 1, 4, 5, 6, 7 și 8 care corespund unor păduri cu areale bine delimitate. Se concentrează în condițiile extreme din nord și din sud ale zonei boreale și altitudinal, până la limita pădurilor în 148 munți și în insulele din Pacific. Aceste păduri includ unităţi din sub-tundra nord Europeană, la altitudini joase şi din zone montane (tipul 1), unități din sub-goletz montan în zona peninsulei Kola și în Karelia, precum și păduri din etajul sub-goletz montan din munții Urali. Toate aceste unități sunt caracterizate de prezența speciei dominante Betula czerepanovii. Partea Europeană a Rusiei este încadrată de aceste tipuri de păduri. În partea de sud-vest a părții Europene a Rusiei, etajul subalpin din munţii Caucaz conţine păduri dominate de B. litwinowii (tipul 6). În extremul Orient, în câmpia hemiboreală străbătuta de fluviul Amur vegetează pădurile cu $B$. davurica (tipul 4 de păduri de mesteacăn) în timp ce zona insulară din Pacificul de nord ce include atât peninsula Kamchatka cât și insula Sakhalin și arhipelagul Kurile include pădurile montane de $B$. ermanii (tipul 5).

\section{Multumiri}

Lucrarea de faţă a fost elaborată în cadrul proiectului dezvoltat în Institutul Botanic Komarov: Organizarea spațială, diversitatea și cartarea covorului vegetal al Eurasiei de nord("Spatial organization, diversity, and mapping of the vegetation cover of Northern Eurasia"). Număr de înregistrare No AAAA-A19-119030690002-5.

\section{Bibliografie}

Ashburner K., McAllister H.A. 2013. The Genus Betula: A taxonomic Revision of Birches. Richmond, Kew Publishing: 300 .

Avrorin N.A., Kachurin M.Kh., Korovkin A.A.1936. Materialy po rastitelnosti Khibinskikh gor [Materials on vegetation of the Khibiny Mountains]. In: Trudy SOPS AN SSSR, seriya Kolskaya. 11: 3-93. (în limba rusă).

Bartalev S.A., Yershov D.V., Isaev A.S., Potapov P.B., Turubanova S.A., Yaroshenko A.G. 2004. Karta lesov Rossiyskoy Federatsii [Map of Russian Federation forests] M 1:14 000 000. Moscow. (în limba rusă).

Belov A.V., Gribova S.A., Ilyina I.S., Isachenko T.I., Kotova T.V. 1985. Rastitelnost taigi na novoi geobotanicheskoi 
karte SSSR dlya vuzov [Taiga vegetation on a new geobotanical map of the USSR for universities]. In: Thematical cartography. Theory, Methods, Practice. P. 151-158. (în limba rusă).

Box E.O., You H.-M, Li D.-L. 2001. Climatic ultra-continentality and the abrupt boreal-nemoral forest boundary in northern Manchuria. A separate offprint. P. 183-200.

Buchwald E. 2005. A hierarchical terminology for more or less natural forests in relation to sustainable management and biodiversity conservation. Third Expert Meeting on Harmonizing Forest-related Definitions. p. 111.

Cristea V., Gafta D., Pedrotti F., Mosciatti G. 2015. Fitosociologia. Trento: TEMI Editrice. 408 p.

Chokkalingam, U., De Jong, W. 2001. Secondary forests: a working definition and typology. International Forestry Revew, 3(1): 19-26.

Czerepanov S.K. 2007. Vascular plants of Russia and adjacent states (the former USSR). Cambridge. $532 \mathrm{p}$.

Degteva S.V. 2001. Klaccifikatsiya bereznyakov podzon yuzhnoy i sredney taigi respubliki Komi. 1. Beresnyaki travyanye (Betuleta herbosa) [Classification of birch forests of middle- and southern-boreal subzones of Komi Republic. 1. Betuleta herbosa]. In: Rastitelnost Rossii. 2: 3-37. (în limba rusă). https://doi.org/10.31111/vegrus/2001.02.3

Dibirov M.D. 2007. Phiziko-geographicheskie i phitotsenoticheskie usloviya proizrastaniya berezy Radde (Betula raddeana Trautv.) v Dagestane [Physical-geographical and phytocoenotical growing conditions of Radde birch (Betula raddeana Trautv.) in Dagestan]. In: Gornye ekosistemy i ikh komponenty: Trudy mezhdunarodnoi konferentsii 13-18 avgusta 2007 g. Part 1. P. 200-201. (în limba rusă).

Dolukhanov A. G.1956. Subalpine krivolesya Caucasus. [Subalpine crooked Kaukasus] - In: Academician V. N. Sukachev to the 75th anniversary of his birth: a collection of works on geobotany, forest science, paleogeography and floristic. M. - L.. 158-170

Dolukhanov A.G. 1939.K poznaniyu kavkazskikh berez sektsii Albae [On the knowledge of Caucasian birches of section Albae]. In: Zametki po sistematike i geografii rasteniy. Tbilisi. 7: 5-19. (în limba rusă).

Geltman V.S. 1958. Tipy berezovykh lecov Polesya [Types of birch forests of Polesye]. In: Sbornik nauchnykh trudov po lesnomu khozyaistvu. Minsk: AN BSSR. 12: 119-134. (în limba rusă).

Geltman V.S. 1982. Geograficheskiy and tipologicheckiy analiz lesnoy rastitelnosti Belorussii [Geographical and tipological analysis of forest vegetation of Belorussia]. Minsk. 326 p. (în limba rusă).

Golgofskaya K.Yu. 1959. K voprosu o vzaimootnosheniyah berezy i kavkazskogo rododendrona $\mathrm{v}$ polose verhnego predela lesa na Severo-Zapadnom Kavkaze[On the relationship between birch and Caucasian rhododendron in the upper limit of the forest in the North-West Caucasus] Trudy Kavkazskogo gosudarstvennogo zapovednika. 5. 170-179.(în limba rusă).

Gorchakovsky P.L. 1966. Flora i rastitelnost vysokogoriy Urala [Flora and vegetation of the Ural highlands]. Sverdlovsk. 270 p. (în limba rusă).
Gorodkov B.N. 1915. Podzona listvennykh lesov v predelakh Ishimskogo uezda Tobolskoy gubernii [Subzone of leaf-bearing forests within Ishim County of Tobolsk Governorate]. In: Trudy pochvenno-botanicheskikh ekspeditsii po issledovaniyu kolonizatsionnykh rayonov Aziatskoi Rossii. Petrograd. 3, 2: 1-198. (în limba rusă).

Hämet-Ahti L. 1987. Mountain birch and mountain birch woodland in NW Europe. In: Phytocoenologia. 15, 4: 449453. https://doi.org/10.1127/phyto/15/1987/449

Ilyina I.S., Lapshina E.I., Lavrenko N.N., Melcer L. I., Romanova E. A., Bogoyavlenskiy B. A., Makhno V. D. 1985. Rastitelnyi pokrov Zapadno-Sibirskoi ravniny [Vegetation cover of the West-Siberian Plain]. Novosibirsk. 250 p. (în limba rusă).

Isachenko T.I., Lukicheva A.N. 1956. Berezovye i osinovye lesa [Birch and aspen forests]. In: Rastitelnyi pokrov SSSR. Moscow; Leningrad. T. 2. P. 319-345. (în limba rusă).

Kabanov N.G. 1972. Kamenno-berezovye lesa v botaniko-geograficheskom i lesovodstvennom otnosheniyakh [Stone-birch forests in botanical-geographical and sylvicultural aspects]. Moscow. 136 p. (în limba rusă).

Karta rastitelnosti SSSR dlya vysshey shkoly [Vegetation map of the USSR for high school]. 1990. Moscow: GUGK. 4 p. (în limba rusă).

Kessel D.S., Shchukina K.V., Pukinskaya M.Yu. 2019. Berezovye lesa Teberdinskogo gosudarstvennogo prirodnogo biosfernogo zapovednika [Birch forests of Teberda State Nature Biosphere Reserve]. In: Flora i zapovednoye delo na Kavkaze: Istoriya i sovremennoye sostoyanie izuchennosti. Pyatigorsk. P. 53-56. (în limba rusă).

Kholod S., Yurkovskaya T. 2013. Vegetation of Lappland reserve and human impact. In: Colloques phytosocioloquiques. Vol. XXIX. Stelvio '70, Camerino. P. 297-303.

Kholod S.S. 1994. Slozhenie and usloviya formirovaniya neodnorodnogo rastitelnogo pokrova gornykh tundr Laplandskogo zapovednika [Composition and conditions of formation of heterogeneous vegetation cover of mountain tundras in Lapland Nature Reserve]. In: Botanicheskii zhurnal. 79, 9: 73-86. (în limba rusă).

Kravchenko A.V. 2007. Konspekt phlory Karelii [Conspectus of the flora of Karelia]. Petrosavodsk. 403 p. (în limba rusă).

Krylov G.V. 1953. Beryozovye lesa Tomskoi oblasti i ikh tipy [Birch forests of Tomsk Region and their types]. Novosibirsk. 123 p. (în limba rusă).

Krylov G.V. 1961. Les Zapadnoi Sibiri [Forests of Western Siberia]. Moscow. 255 p. (în limba rusă).

Kryuchkov V.V. 1960. Faktory, opredelyayushchie verkhnie predely rastitelnykh poyasov $\mathrm{v}$ Khibinskikh gorakh [Factors controlling the upper limits of vegetation belts in the Khibiny Mts.]. In: Trudy Khibinskoi geograficheskoi stantsii. 1: 174-214. (în limba rusă).

Lapshina E.I. 1963. Berezovye lesa lesostepnogo yugo-vostoka Zapadnoi Sibiri (Novosibirskaya oblast i Altayskiy kray) [ Birch forests of the south-east of West Siberia (Novosibirsk Region and Altay Territory]. In: Trudy TsSBS SO RAN. Novosibirsk. 3: 103-130. (în limba rusă). 
Lavrenko N.N. 1985. Berezovye i osinovye lesa [Birch and aspen forests]. In: Rastitelnyi pokrov Zapadno-Sibirskoi ravniny. Novosibirsk. P. 125-138. (în limba rusă).

Lipatova V.V. 1969. Rastitelnye assotsiatsii podzony khvoyno-shirokolistvennykh lesov (na primere klyuchevykh uchastkov) [Vegetation associations of conifer-broadleaved forest subzone (by the example of key areas)]. In: Amurskaya taiga (kompleksnye botanicheskie issledovaniya). Leningrad. P. 53-69. (în limba rusă).

Moore, P.D. 1979. Next in succession. Nature, 282: 361-362. https://doi.org/10.1038/282361b0

Nekrasova T.P. 1935. Rastitelny pokrov Laplandskogo zapovednika [Vegetation cover of Lapland Nature Reserve]. In: Trudy Leningradskogo obshchestva estestvoispytatelei. 64, 2: 239-272. (în limba rusă).

Nekrasova T.P. 1938. Rastitelnost alpiyskogo i subalpiyskogo poyasov Chuna-tundry na Kolskom poluostrove [Vegetation of alpine and subalpine belts of the Chuna-Tundra in the Kola Peninsula]. In: Trudy Laplandskogo gosudarstvennogo zapovednika. 1: 7-176. (în limba rusă).

Neshataev V.Yu., Neshataeva V.Yu. 1993. Birch forests of the Lapland state reserve. - In: Aerial pollution in Kola peninsula: Proc. International Workshop, Apr. 14-16, 1992. St.Petersburg; Apatity. P. 328-338.

Neshataeva V.Yu. 2009. Rastitelnost poluostrova Kamchatka [Vegetation of the Kamchatka Peninsula]. Moscow. 537 p. (în limba rusă).

Orlova N.I. 1976. Sem. Betulaceae S.F.Gray. Berezovye [Fam. Betulacae S.F.Gray. Birches]. In: Flora Severo-Vostoka Evropeiskoi chasti SSSR. Leningrad. 2: 152-161. (în limba rusă).

Orlova N.I. 1978. O statuse dvukh vidov berez [On the status of the two species of birch]. In: Vestnik Leningradskogo Universiteta. Seriya 3 (biologya). 1: 56-62. (în limba rusă).

Palmé A.E., Su Q., Palsson S., Lascoux M. 2004. Extensive sharing of chloroplast haplotypes among European birches indicates hybridization among Betula pendula, B. pubescens and B. nana. Molecular Ecology, 13: 167-178. https://doi.org/10.1046/j.1365-294X.2003.02034.x

Ramenskaya M.L. 2015a. K tipologii lesotundrovykh i gornykh bereznyakov [On the typology of forest-tundra and alpine birch stands]. In: Marianna Leontievna Ramenskaya (zhizn i nauchnaya deyatelnost, izbrannoye, perevody). Apatity. P. 133-138. (în limba rusă).

Ramenskaya M.L. 2015b. Rastitelnost Pechengskikh tundr [Vegetation of the Pechenga tundras]. In: Marianna Leontievna Ramenskaya (zhizn i nauchnaya deyatelnost, izbrannoye, perevody). Apatity. P. 139-153. (în limba rusă).

Sabatini, F., Keeton, N.S., Lindner, M......Kumerle, T. 2020. Protection gaps and restoration opportunities for primary forests in Europe. Diversity and Distributions, 267: 1646-1662. https://doi.org/10.1111/ddi.13158

Semenova-Tyan-Shanskaya A.M., Sochava V.B. Khvoyno-shirokolistvennye lesa [Coniferous-broadleaved forests]. In: Rastitelnyi pokrov SSSR: Poyasnitelnyi tekst k geobotanicheskoi karte SSSR. Moscow; Leningrad. P. 346-364. (în limba rusă).

Shennikov A.P. 1938. Obshchie zamechaniya k metodike marshrutnogo geobotanicheskogo issledovaniya [General remarks on the route vegetation survey method]. In: Metodika polevykh geobotanicheskikh issledovaniy. Moscow; Leningrad. P. 5-26. (în limba rusă).

Shennikov A.P. 1964. Vvedenie v geobotaniku [Introduction to geobotany]. Leningrad. 447 p. (în limba rusă).

Skvortsov A.K. 2002. Novaya sistema roda Betula L.Beryoza [A new system of genus Betula L. - Birch]. In: Byulluten MOIP. Otdeleniye biologii. 107, 5: 73-76. (în limba rusă).

Sochava V.B. 1979. Rastitelnyi pokrov na tematicheskikh kartakh [Vegetation cover on thematic maps]. Novosibirsk. 190 p. (în limba rusă).

Terieiev, A., Olshanskyi, J., Gailing, O., Krutovsky, K.V., 2019. Taxonomy of dark and white birches related to Betula pendula and Betula pubescens (Betulaceae) in Ukraine based on both morphological and DNA markers. Botanical Journal of the Linnean Society, 191(10: 142154. https://doi.org/10.1093/botlinnean/boz031

Tumadzhanov I. I. 1960b. Krivolesya i stlaniki basseyna Teberdy v svyazi s landshaftnymi smenami subalpiyskogo poyasa na severnom sklone Bolshogo Kavkasa [Crooked forests and prostrate scrub of the Teberda R. basin in connection with landscape changes of the subalpine belt on the northern slope of the Greater Caucasus]. - In: Problemy botaniki. Vol. 5 Moscow; Leningrad. P. 148-162. (în limba rusă).

Tumadzhanov I. I. 1980. Luga i krivolesya [Meadows and crooked forests]. In: Rastitelnost evropeiskoi chasti SSSR. Leningrad. P. 198-202. (în limba rusă).

Tumadzhanov I.I. 1960a. K tipologii subalpiyskikh krivolesiy Teberdinskogo zapovednika [On the typology of subalpine crooked forests in the Teberda Nature Reserve]. In: Trudy Teberdinskogo zapovednika. 2: 63-105. (în limba rusă).

Tzvelev N.N. 2002. O rodakh Betula L. i Alnus Mill (Betulaceae) v Vostochnoi Evrope. [On the genera Betula L. and Alnus Mill. (Betulaceae) in Eastern Europe]. In: Novosti sistematiki vyschikh rasteniy. 34: 47-73. (în limba rusă).

Vasilevich V.I. 1996. Nezabolochennye berezovye lesa Severo-Zapada evropeiskoi Rossii [Upland birch forests of the Nord-West of European Russia]. In: Botanicheskii zhurnal. 81, 11: 1-13. (în limba rusă).

Vasilevich V.I. 1997. Zabolochennye berezovye lesa Severo-Zapada evropeiskoi Rossii [Paludified birch forests of the Nord-West of European Russia]. In: Botanicheskii zhurnal. 82, 1: 19-29. (în limba rusă).

Yurkovskaya T.K. 1993. Rastitelny pokrov Karelii [Vegetation cover of Karelia]. In: Rastitelny mir Karelii i problemy ego okhrany. Petrozavodsk. P. 8-36. (în limba rusă).

Yurkovskaya T.K., Polozova T.G., Snitko N.P. Korennye berezovye lesa na analiticheskoy karte Rossii [Primary birch forests on the analytical map of Russia]. In: Botanicheskii zhurnal. 97, 10: 1259-1275. (în limba rusă).

Zinserling G.D. 1932. Geografiya rastitelnogo pokrova severo-zapada evropeiskoi chasti SSSR [Geography of vegetation cover of the North-West of the European part of the USSR]. In: Trudy Geomorphologicheskogo instituta AN SSSR. Leningrad. 376 p. (în limba rusă). 